\title{
ASSESSMENT OF LANDSCAPE-RECREATIONAL CAPACITY OF NORTH KAZAKHSTAN REGION
}

\author{
Gulnur Z. MAZHITOVA* \\ National Research Tomsk State University, Department of Geography, \\ 36 Lenina st., 634000, Tomsk, Russian Federation, e-mail: mazhitova_gulnur@mail.ru
}

\author{
Sergey V. PASHKOV \\ North Kazakhstan State University named after M. Kozybayev, \\ Department of Geography and Ecology, 86 Puschkina st., \\ 1500oo, Petropavlovsk, Republic of Kazakhstan, e-mail: sergp2001@mail.ru
}

Jan A. WENDT

Gdańsk University, Institute of Geography, Bażyńskiego Str. 4, 80-309 Gdańsk, Poland, e-mail: jan.wendt@ug.edu.pl

\begin{abstract}
Citation: Mazhitova, G.Z., Pashkov, S.V., \& Wendt J.A. (2018). ASSESSMENT OF LANDSCAPE-RECREATIONAL CAPACITY OF NORTH KAZAKHSTAN REGION. GeoJournal of Tourism and Geosites, 23(3), 731-737. https://doi.org/10.30892/gtg.23309-323
\end{abstract}

\begin{abstract}
The article is concerned with the study of landscape and recreational capacity of North Kazakhstan Region (NKR). The paper presents the results of landscapes studies of North Kazakhstan Region with regard to their suitability and degree of recreation favorability. Here were studied recreational conditions and resources of the regional landscapes, as well as features of their territorial distribution and possibility of use for the recreational purposes. Recreational assessment of the region's landscapes was carried out on the basis of the developed system of criteria and their properties. The calculations were carried out taking into account the significance (weight) of each selected criterion and indicator using the method of scoring. The assessment was carried out within the boundaries of landscape areas. The obtained results made it possible to perform zoning of the territory of the region in terms of recreational capacity level, degree of favorability and possibility of organizing recreational activities of the population.
\end{abstract}

Key words: landscape-recreational capacity, assessment, landscape, recreational conditions and resources.

\section{INTRODUCTION}

The study of recreational conditions and resources of the living environment of the population is a special area of comprehensive medical and geographical study of the territory. Along with economic, social, environmental conditions, the availability of

\footnotetext{
* Corresponding author
} 
recreational resources, the possibility of organizing recreational activities of the population, recreation and improvement of the population is one of the factors in the formation of public health (Prokhorov \& Ryaschenko, 2012). The majority of recreational activities of the population is reduced to recreation within or near the place (region) of permanent residence, and short-term outside trips for recreational and tourist purposes. In this regard, the main attention should be paid to the study of local and regional natural recreational resources, their availability, suitability and degree of favorability to meet the recreational needs of the population. At the regional and local level, the object of such research concerns landscapes (Nikolayev, 2003). In this case, landscapes are considered not just as geographical complexes and their corresponding combinations of natural conditions that make up the living environment of the population, but also as objects of recreational use. An important aspect of this kind of research is the definition of recreational capacity of landscapes, identification of recreational conditions and resources, assessment of their quality and availability, the possibility of using for recreation, health and treatment of the population (Vedenin \& Miroshnichenko, 1969; Preobrazhenskiy, 1975; Ilieş \& Wendt, 2015; Gozner et al., 2016).

The purpose of the study is to assess the landscape and recreational capacity of the NKR territory. The object of the research concerned landscape (physical and geographical) areas of NKR, the subject of the research is their recreational conditions and resources, recreational capacity.

\section{RESEARCH MATERIALS AND APPROACHES}

Theoretical and methodological basis of the study included the approaches and research results of domestic and foreign scientists in the field of medical and recreational geography (Keller \& Kuvakin, 1998; Ilies et al., 2014; Prokhorov \& Ryaschenko, 2012; Vedenin \& Miroshnichenko, 1969; Mukhina, 1973; Preobrazhenskiy, 1975; Eringis, 1975; Kotlyarov, 1978; Mowforth \& Vunt, 1998; Nikolayev, 2003; Ryaschenko et al., 2008; Meade \& Emch, 2010; Chizhova, 2011; Herman \& Wendt, 2011; Ungureanu et al., 2015). Literature and cartographic sources, statistical and reference materials for the period 2000-2016, the results of field landscape and geographical research of 2016-2017 were used as the initial materials. The study used various methods: comparative-geographical, cartographic, mathematical and statistical, expert approach, method of scoring, field methods, GIS, etc.

The study of the subjective perception and the results of the local population assessment of the recreational capacity of natural complexes and the degree of their favorability for recreational activities were carried out using the method of questioning. The results of the survey are also used to perform a collective expert evaluation to determine the factors of significance of the selected criteria. In total, more than 100 respondents took part in the sociological survey. The questionnaire was developed taking into account the selected evaluation criteria and regional landscape and geographical features of the study area. When determining the criteria and developing a scale for assessing the recreational capacity of landscapes we used methods and approaches of recreational geography, some components of the methods of recreational research of natural-territorial complexes and their components (Prokhorov \& Ryaschenko, 2012; Vedenin \& Miroshnichenko, 1969; Mukhina, 1973; Nefedova et al., 1973; Eringis et al., 1975; Frolova, 1994; Kochurov \& Buchatskaya, 1997; Bredikhin, 2003; Ryashchenko et al., 2008; Ilieş, \& Josan, 2009; Chizhova, 2011). In addition, the selection of criteria and parameters of evaluation took into account the medical and geographical study position of the recreational conditions and resources as a factor in public health formation.

The assessment consisted of several stages. At the initial stage, the previous experience and results of landscape and recreational research, methods and approaches 
for assessing the recreational capacity of the territory were studied. Further, we have collected and processed the necessary data and materials, inventory analysis and systematization of natural and anthropogenic recreational facilities of the region, performed field landscape studies, studied the recreational conditions of the region. An important step was the definition of assessment units, assessment criteria, conducting a survey and expert assessment and determining the significance (weight) of the selected criteria, the development of the assessment scale. At the final stage, we carried out the assessment itself and identified the areas with the greatest recreational attractiveness and recreational capacity. As assessment units we have adopted physical-geographical, landscape areas with the boundaries determined by the physical and regional geographical zoning, developed by V.A. Nikolayev (Collection of Maps of Northern Kazakhstan, 1970). We singled out the following areas within the region: 1. Petropavlovskiy; 2. Presnovskiy; 3. Bulayevskiy; 4. Yavlenskiy; 5. Chapanevskiy; 6. Maryevskiy; 7. Karasuskiy; 8. Shagalalinskiy; 9. Ulkenkaraoyskiy; 10. Kyzyltuyskiy; 11. Ayirtauskiy; 12. Imantauskiy; 13. Kamennobrodskiy; 14. Kokshetauskiy; 15. YesilAkkanburlukskiy; 16. Seletinskiy; 17. Seletytenizskiy (Figure 1).

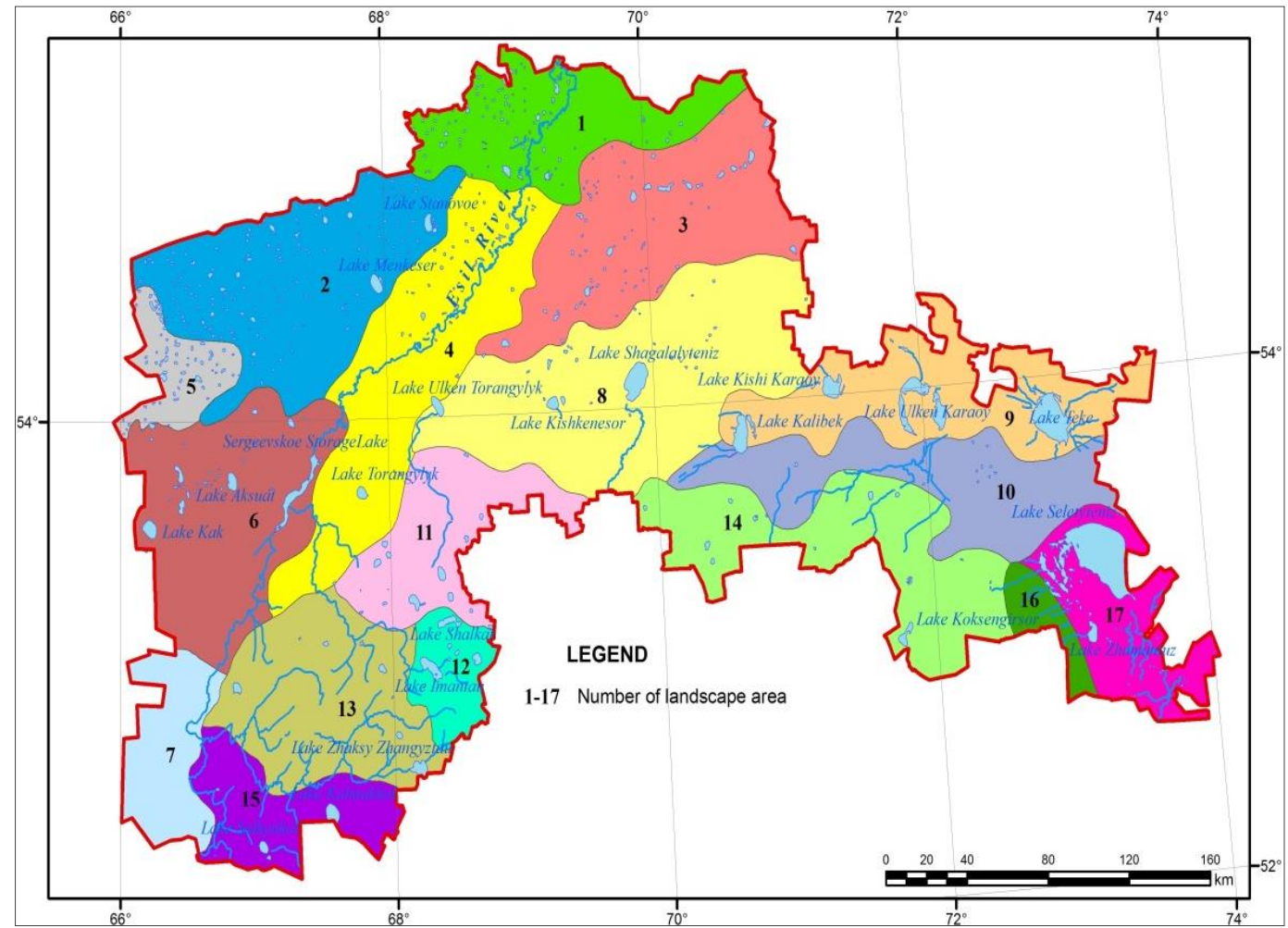

Figure 1. Map-Chart of Landscape areas of North Kazakhstan Region (Landscape areas are named in the text hereof)

A number of criteria and properties which were combined into several groups have been defined for the assessment:

1. Comfortability of climatic conditions determined mainly by the number of days with favorable weather conditions for outdoor recreation during the year (the number of days of sunshine, the sum of temperatures above $10^{\circ} \mathrm{C}$ ). 
2. The terrain structure (altitude, surface slope and density of terrain dissection).

3. Natural and aesthetic appeal, expressiveness of the landscape was determined on the basis of visual assessment of the landscape of the dominant tracts and the diversity of landscape elements. diversity).

4. Natural attractions (the number of unique natural objects per area unit, their

5. Cultural and historical monuments (number per area unit).

6. Water bodies (availability of lakes, rivers, their number, area).

7. The nature of vegetation (species diversity of flora, the degree of forest cover).

8. Therapeutic value (availability of therapeutic mineral waters and mud deposits).

9. Commercial and recreational value (species diversity of commercial animals and birds, number of species of mushrooms, berries).

10. Landscape diversity (the coefficient of landscape diversity (inhomogeneity)) (Pozachenyuk, 2015; Sokolov, 2016; Collection of Maps of Northern Kazakhstan, 1970).

11. Availability of special nature protection areas (number, occupied area, \%).

12. The existing recreational infrastructure and arrangement of the territory (number of stationary establishments for rest and tourism, availability of tourist routes).

13. Suitability of the landscape for placement of recreational objects and convenience of their engineering arrangement (degree of economic development and use of the territory, \%).

14. The degree of anthropogenic transformation; transformation of natural landscapes was determined on the basis of the anthropogenic transformation indicator (Kat).

15. Safety from the point of view of geomorphological, hydrochemical, landscape-epidemiological risks: dangerous natural phenomena - high waters, floods, strong winds, etc. (number of reported cases, duration in days); natural-geochemical anomalies (area, \%); natural focal diseases (number of cases).

Table 1. Scale of landscape and recreational

capacity assessmentof North Kazakhstan Region (fragment)

\begin{tabular}{|c|c|c|c|c|c|c|c|}
\hline $\begin{array}{l}\text { No. } \\
\Pi / \Pi\end{array}$ & $\begin{array}{l}\text { Significance, } \\
\mathrm{K}\end{array}$ & Indicators & \multicolumn{5}{|c|}{ Parameter Range } \\
\hline 1 & 2 & 3 & \multicolumn{5}{|c|}{4} \\
\hline \multicolumn{8}{|c|}{ Environmental Conditions } \\
\hline 1 & 5 & Sunshine duration, hours per year & 2100 & 2050 & 2000 & 1950 & 1900 \\
\hline 2 & 5 & $\begin{array}{l}\text { Accumulated temperatures over } \\
10^{\circ} \mathrm{C} \text {, degrees }\end{array}$ & 2400 & 2300 & 2200 & 2100 & 2000 \\
\hline \multicolumn{8}{|c|}{ Terrain structure } \\
\hline 3 & 4 & Absolute altitude, $\mathrm{m}$ & $>1000$ & - & $500-1000$ & - & $<500$ \\
\hline 4 & 3 & Surface slope, degrees & $>12$ & - & $12-6$ & - & $<6$ \\
\hline$\ldots$ & $\ldots$ & $\ldots$ & $\ldots$ & $\ldots$ & $\ldots$ & $\ldots$ & $\ldots$ \\
\hline 7 & 5 & $\begin{array}{l}\text { Natural and aesthetic appeal of } \\
\text { the landscape, points }\end{array}$ & 5 & 4 & 3 & 2 & 1 \\
\hline$\ldots$ & $\ldots$ & $\ldots$ & $\ldots$ & $\ldots$ & $\ldots$ & $\ldots$ & $\ldots$ \\
\hline 13 & 4 & Forest cover, \% & $>10$ & $10-8$ & $7-5$ & $4-2$ & $<2$ \\
\hline$\ldots$ & $\ldots$ & $\ldots$ & $\ldots$ & $\ldots$ & $\ldots$ & $\ldots$ & $\ldots$ \\
\hline 17 & 4 & $\begin{array}{l}\text { Degree of landscape diversity, unit } \\
\text { fractions }\end{array}$ & 1 & $0.9-0.7$ & $0.6-0.4$ & $0.3-0.2$ & 0.1 \\
\hline \multirow[t]{2}{*}{$\ldots$} & $\ldots$ & $\ldots$ & $\ldots$ & $\ldots$ & $\ldots$ & $\ldots$ & $\ldots$ \\
\hline & & Assessment, points & 5 & 4 & 3 & 2 & 1 \\
\hline
\end{tabular}


The selected criteria and their properties were measured in absolute units and converted into relative or provisional ones (points). In order to convert absolute values into relative units, we have adopted a five-point system: the lowest score (1) characterizes the minimum value of the indicator or its absence, the highest (5) means the maximum. The value of points was determined taking into account the absolute values of each criterion considered. The highest value and criterion property is assigned the highest score.

A fragment of the assessment scale is shown in the Table 1.

The calculations took into account the significance (weight) of the selected criteria by introducing the significance factors $(\mathrm{K})$, which were identified on the basis of expert and survey evaluation. Points on all analyzed criteria were summed taking into account the factors of their significance. Scores on indicators of anthropogenic transformation, the degree of economic development and use, safety of landscapes were subtracted from the total score. The integral estimation is calculated according to the formula modified for this study and based on the methods presented in the works of (Arkhipova, 2006; Stulyshapku, 2006):

$$
R p=\frac{C_{1} K_{1}+C_{2} K_{2}+C_{3} K_{3}+\ldots+C_{n} K_{n}}{n},
$$

where $R p$ - integral estimate (average point) of recreational capacity, $C$ estimates of the $i^{\text {th }}$ criterion in scores, $K$ - significance factor of the $i^{\text {th }}$ criterion, $n-$ number of criteria.

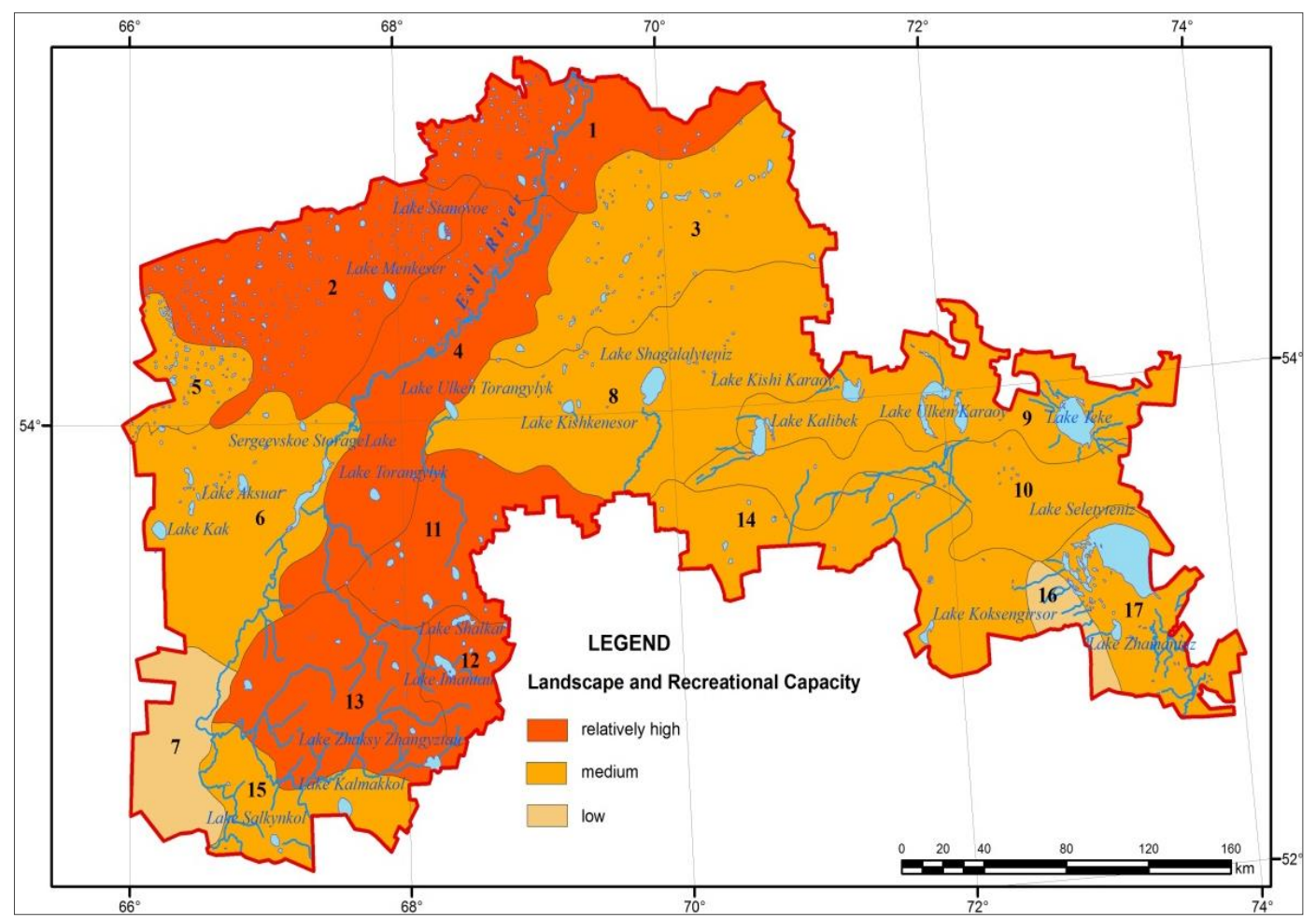

Figure 2. Assessment Map-Chart of Landscape and Recreational Capacity of North Kazakhstan Region 
The calculations were carried out for each landscape area. The obtained weighted average scores allowed to assess the landscape and recreational capacity of the region under study and to identify landscape areas with high, medium and low recreational capacity and attractiveness. The map of assessment of recreational capacity of landscape areas of North Kazakhstan region can be found in Figure 2.

\section{RESULTS AND DISCUSSION}

The highest value of scores was identified for the districts of Imantau $(15,0)$, Petropavlovsk (14,5), Ayirtau (13,7) and Presnovka (13,3). The areas of attractive recreation also included Kamennobrodskiy $(10,3)$ and Yavlenskiy $(10,1)$ districts. Within these areas there is concentrated a significant variety of natural, cultural and historical recreational facilities. Natural complexes can be characterized by significant recreational capacity and aesthetic appeal. The state and development of recreational infrastructure has a high enough level to meet the recreational needs of the population.

The lowest scores were received by districts of Seletynskiy $(4,9)$ and Karasuskiy $(3,6)$. In these areas, there is a limited number of objects of recreational importance. They have low level of development of recreational infrastructure and arrangement of the territory for the population recreation. All stated above adversely affects the recreational attractiveness of the areas. Bulayevskiy, Chapayevskiy, Maryevskiy, Shagalalinskiy, Ulkenkaraoyskiy, Kyzyltuyskiy, Kokshetauskiy, YessilAkkanburlukskiy, Seletytenizskiy areas have the value weighted average of scores varying in the range of 5,0-9,3 and are referred to the group of medium recreational capacity and recreational appeal. In general, these areas are characterized by favorable landscape and geographical conditions for recreation. The limiting factor for recreational activities is rather high agricultural development of the territory.

\section{CONCLUSION}

The assessment of landscape and recreational capacity by means of scoring method is rather objective upon availability of the extensive basic material (archive, statistical and cartographic data, materials of field landscape researches, etc.).

The used method of assessing the landscape and recreational capacity of the North Kazakhstan Region or its individual approaches can be used for recreational research in other regions. The conducted research allowed determining the territory within the North Kazakhstan Region with the most favorable landscape and geographical conditions and a sufficiently high recreational capacity for recreational activities and recreation. The results can serve as an information basis for further research on the creation of a regional program for development of the recreational industry and improvement of tourist and recreational attractiveness of the region.

\section{REFERENCES}

Arkhipova, I.V. (2006). Medical and geographical assessment of climatic comfort of the Altai territory. Abstract of thesis... of Cand. Sc. (Geography). Barnaul: Institute for Water and Environmental Problems, SB RAS, 22 p. Bredikhin, A.V. (2003). Relief as a recreational condition and tourism resource. Bulletin of Moscow University. Series 5. Geography, no.1, pp. 58-59.

Chizhova, V.P. (2010). Recreational Landscapes: Sustainability, Regulation, Management. Smolensk, Oykumena, p. 328.

Eringis, K.I., \& Budryunas, A.R. (1975). Essence and Approaches of Detailed Ecological and Aesthetic Study of Landscapes. Landscape Ecology and Aesthetics. Vilnius: Mintis, pp. 107-159.

Frolova, M.Y. (1994). Evaluation of the Aesthetic Qualities of Natural Landscapes. Bulletin of Moscow University. Series 5. Geography, no. 2, pp. 30-33. 
Gozner, M., Josan, I., Baias, S., Măduta, F.M., (2016), The Religious Attractions - An Expression of Authenticity in the Territorial System Albac - Arieşeni and Alba County (Romania). GeoJournal of Tourism and Geosites, Year VIII, Volume 15, Oradea-Gdansk, Romania-Poland, Editura Universităţii din Oradea.

Herman, G.V., \& Wendt, J. A. (2011). Development and promotion of tourism, an extra chance in maintain and assenting the identity and specificity of Oaş land. GeoJournal of Tourism and Geosites, year IV, vol. 7, no. 1, pp. 97-95.

Ilieş, D.C., \& Josan, N. (2009). Geosites and relief. GeoJournal of Tourism and Geosites, year II, vol. 3, no. 1, pp. $78-85$.

Ilieş, A., Wendt, J.A., (2015). Tourism geography. The basic of theory and application issues. [Geografia turystyczna. Podstawy teorii i zagadnienia aplikacyjne]. Wydawnictwo AWFiS, Gdańsk.

Ilies A. (Coord.), Baias S, Baias Iuliana, Blaga L., Buhaș S., Chiriac A., Ciocan Janeta, Dăncuș M., Deac Anca, Dragoș P., Dumitrescu G., Gaceu O., Godea I., Gozner Maria, Grama V., Herman G., Hodor N., Hurley P., Ilieș Dorina, Ilieș Gabriela, Ilieș M., Josan Ioana, Leșe G., Măduța F., Mojolic Diana, Morar C., Olaru M., Stașac M., Stupariu M., Sturza Amalia, Ștefănescu B., Tătar Corina, Vârnav R., Vlaicu M., \& Wendt J., (2014), Crisana-Maramures. Atlas geografic al patrimoniului turistic/ Geographical atlas of tourism heritage, 302 pp., Editura Universității din Oradea, ISBN 978-606-10-1298-5.

Keller, A.A., \& Kuvakin, V.I. (1998). Medical Ecology. Saint-Petersburg.: Petrogradskiy and Co. p. 256.

Kotlyarov, Y.A. (1978). Geography of Tourism and Recreation. Formation and Development of Territorial Recreation Complexes. M.: Mysl, p. 238.

Kochurov, B.I., \& Buchatskaya, N.V. (2007). Assessment of the Aesthetic Capacity of Landscapes. The South of Russia: Ecology, Development, no. 4, pp. 25-34.

Meade, M.S., \& Emch, M. (2010). Medical Geography. 3d ed. New York: Guilford, p. 498.

Mowforth, M. (1998). Tourism and Sustainability: New Tourism in the Third World /M. Mowforth, I. Vunt. London, p. 363.

Mukhina, L.I. (1973). Principles and methods of technological assessment of natural complexes. M.: Nauka, p. 96.

Nefedova, V.B., Smirnova, Y.D., \& Shvidchenko, L.G. (1973). Approaches of Recreational Assessment. Bulletin of MSU. Series 5. Geography, no. 5, pp. 25-29.

Nikolayev, V.A. (2003). Landscape. Aesthetics and Design. M.: Aspect Press, p. 176.

Pozachenyuk, E.A. (2015). Landscape diversity of Crimea. Scientific Notes of V.I. Vernadsky Crimean Federal University. Geography. Geology, vol. 1 (67), no 4, pp. 37-50.

Prokhorov, B.B., \& Ryaschenko, S.V. (2012). Medical Geography of Siberia. Irkutsk: Publishing House of Geography Institute named after V.B. Sochava, SB RAS, p. 223.

Ryaschenko, S.V., Bogdanov V.N., \& Romanova O.I. (2008). Regional Analysis of Recreational Activities. Irkutsk: Publishing House of Geography Institute named after V.B. Sochava, SB RAS, p. 143.

Sokolov, A.S. (2016). Cartographic analysis of regional characteristics of landscape diversity of Belarus. Pskov Regional Journal, no 4(28), pp. 59-70.

Stulyshapku, V.O. (2006). Assessment of environmental and social comfort of living at the local level: Abstract of thesis of Cand. Sc. (Geography). Kaluga: Kaluga State Pedagogical University named after K.E. Tsiolkovsky, 20 p.

Ungureanu, M., Dragota, C., Ilieş, D.C., Josan, I., \& Gaceu, O. (2015). Climatic and bioclimatic touristic capacity of Padis Karst Plateau of the Bihor Mountains. Journal of Environmental Protection and Ecology, vol. 16, no 4, pp. 1553-1559.

Vedenin, Y.A., \& Miroshnichenko, N.N. (1969). Assessment of natural conditions for recreation. Academy of Science of the USSR. Geography Series, no. 4, pp. 46-53.

** Collection of Maps of Northern Kazakhstan. (1970). M.: State Department of Geodesy and Cartography, p. 208.

*** Landscape Ecology and Aesthetics. (1975). Edited by K.I. Eringis. Vilnius, p.250.

*** The theoretical basis of recreational geography. (1975). Exec. edit. V.S. Preobrazhenskiy. M.: Nauka, p 224.

Submitted:

26.06.2018
Revised:

26.10.2018
Accepted and published online 29.10.2018 